\title{
EFFECT OF INSTRUCTIONAL MATERIALS ON THE TEACHING AND LEARNING OF BASIC SCIENCE IN JUNIOR SECONDARY SCHOOLS IN CROSS RIVER STATE, NIGERIA
}

\author{
BEATRICE ARISA AROP, FELICIA IMEH UMANAH AND OJI EKPO EFFIONG
}

(Received 17, November 2014; Revision Accepted 13, January 2015)

\begin{abstract}
This study examined the effect of instructional materials on the teaching and learning of Basic Science in Junior Secondary Schools in Cross River State. The study examined the role of instructional materials in the science classroom and how instructional materials have affected the teaching and learning of Basic Science. The study employed quasi experimental design. Two research questions and two hypotheses guided the study. 240 students were randomly selected by simple ballot method from four secondary schools in Biase Local Government Area of Cross River State. A 20-item test called Diffusion Achievement Test [DAT] constructed by the researcher was used to collect data for the study. The test had a reliability of 0.86 . Scores generated from pretest and post-test were analyzed using mean, standard deviation and independent t-test. The result showed that the use of instructional materials have a favourable effect on students' achievement in science concepts. The result also indicated that there is a significant difference in the mean achievement scores of students with females having a higher mean score than males. Recommendations were made among others that teachers should source for instructional materials for effective lesson delivery.
\end{abstract}

\section{INTRODUCTION}

Instructional materials are materials which assist teachers to make their lessons explicit to learners. They are used to transmit information, ideas and notes to learners (Ijaduala 1997).Usman and Adewumi (2006) state that instructional materials can be referred to as the widely variety of equipment and materials used for teaching/learning by teachers to stimulate self-activity on the part of the pupils. Instructional materials include both visual and audio-visual equipments. Visual equipments are those materials that you see. These include; flashcards, posters, charts, textbooks, real objects, models, chalkboard, and so on. While Audio-visual materials are those materials that stimulate both the visual (sight) and audio (hearing) senses.
Examples are; computers, tape recorder, radios, videos, televisions among others.

Their importance in the teaching/ learning process is not to be over-emphasized.

Brown (2000) summarized the role of instructional materials as follows:

a. It promotes meaningful communication, hence effective learning

b. It ensures retention, thus making learning more permanent.

c. It helps to overcome the limitation of classroom by making the inaccessible accessible, This is especially true of films, filmstrips and so on

d. They provide a common experience upon which other learning can be developed. They stimulate and motivate students to learn.

Beatrice ArisaArop,Department of Integrated Science, Cross River State College of Education, Akamkpa, Cross River State Nigeria

Felicia ImehUmanah,Department of Science Education, Akwa-Ibom State University, Akwa-Ibom State, Nigeria.

Oji EkpoEffiong, Department of Integrated Science, Cross River State College of Education, Akamkpa, Cross River State Nigeria 
e. They encourage participation especially if students are allowed to manipulate materials used.

Despite all these roles of instructional materials, most teachers still teach in our schools without instructional materials, reasons being that they are not available or some concepts do not require instructional materials. However some conceived that instructional materials cannot be improvised and some reason that instructional materials are too difficult to manipulate or that instructional materials waste a lot of time in the classroom. This paper therefore examined the roles of instructional materials in the teaching and learning of basic science. The paper also looked at the effect of instructional materials in the teaching and learning of certain concepts in basic science. The paper wants to answer some fundamental questions like whether teachers use instructional materials in the teaching of basic science and the influence of those materials in the teaching and learning of certain concepts in basic science.

\section{The roles of instructional materials in the science classroom}

Instructional materials are highly important for teaching especially for inexperienced teachers. The teachers rely on instructional materials in every aspect of teaching (Crist 2014). They need materials for background information on the subjects they are teaching.Young teachers find it difficult to express themselves when they enter the classroom.Therefore they need instructional materials to help them. Teachers often use instructional materials for lesson planning.

These materials are also needed by teachers to assess the knowledge of their students.Teachers often assess students by assigning tasks, creating projects and administering examinations. Instructional materials are essential for all these activities (Crist 2014).

These materials can also help teachers create assignment and project ideas for students. Teachers are required to use several different methods to assess their students in order to provide the most accurate assessments.Instructional materials often provide innovative and creative ways to assess students' performance. It is hard to imagine any teacher who is capable of teaching effectively without accompaniment of instructional materials.In addition to this, any teacher who is deprived of instructional materials must likely experience stress and anxiety on daily basis (Crist 2014).Instructional materials are also designed to develop the learner to achieve his/her desires objectives in a learning situation.Instructional materials bringscience to bear in the classroom.

Offorma in Usman and Adewumi (2006) stated that successful implementation of any curriculum is fully dependent on the quality and quantity of instructional materials available to teachers and pupils for use in schools. Instructional materials stimulate learner'sinterest; help both the teacher and the learner to overcome physical limitation during presentation of subject matter. Similarly, materials enrich learning and make it more pleasurable. They are used as checks to the teachers' knowledge and means of transmission. Instructional materials also give the teacher the air of guidance, coordination, supervision and more time for correction, brightenthe classroom and bring variety in the class lesson (Eya 2004). Usman (2002) described instructional materials as information carrying technologies that can be used for instruction.Instructional materials have always held out in their different ways, the bright hope of delivery educational information and experiences widely, quickly, vividly with realism and immediacy that printed media could hardly achieve. A teacher for instant can explain and describe a pipette or burette but it is very hard to tell the students exactly what a pipette or burette looks like without a picture for clarity. The picture of a pipette or burette is an instructional material that would help the students to understand the lesson. Betiku (2000) explained that the term instructional material comprise all available and accessible, theoretical, practical and skill oriented resources, which facilitate the learningacquisition and evaluation of vocational technical skills. According to him they integrate all the devices that assist in transmitting the facts, skills, attitudes and knowledge to the learners within the instructional system and as may be applied in the word of work.

Usman and Adewumi (2006) observed that instructional materials have been found to enhance the quality of the learning experience for learning in many ways. Among them are; they improve multi-sensory and multi-image factors responsible for inability of teachers to improvise instructional materials for the teaching and learning of science. 


\section{Effect of Instructional Materials in the} teaching and learning process

The age at which children enter primary school today makes the use of instructional materials very expedient. This age between $3-9$ years falls within Piaget concrete and preoperational stages of intellectual development. However Inyang-Abia (1994) and Maduabum (2000) asserted that various devices exist that can be employed to assist in the teaching learning process especially in the secondary Schools.Such devices vary from simple locally made to complex and sophisticated instructional media like radio sets, televisions, film trips, projectors, computers, and so on. Some of them are designed and cannot be available in the child's ordinary classroom experience.

The teacher's task as a communicator, facilitator, modelin identification of figures, can be supported by a wise use of a variety of instructional materials that expand significantly.Most research findings from the works of Sisteiland Harrison (2001), Inyang-Abia (2000) emphasized the use of instructional materials as aids for effective learning. Nursel (2001) noted that availability and application of instructional materials is advancement in teaching. He stated that instructional materials do not only help to bring about an enhanced respect for the teachers knowledge of the subject butinstructional materials are important because with them learners have a clear view of what is being taught. It helps in getting attention of the students. With instructional materials the class is more realities and it gives a view point on the topic.

Instructional materials help the teacher to teach well as to make her lesson clear and understandable to the students Ogunleye (2002) and (Crist 2014)reported that instructional materials were inadequate in secondary Schools in Nigeria. They further stated that the available ones are not usually in good conditions.

However, a professionally qualified science teacher no matter how well trained would be unable to put his ideas into practice if the school setting lacks the equipment and materials necessary for him or her to translate his/her competence into reality. Thus,science is resource intensive, and in a period of economic recession, it may be very difficult to find some of the electronic gadgets and equipment for theteaching and learning of basic science in schools. Thus simple materials are needed for scientific instructions.

Kindler as quoted byFakunle(2008) declared that people generally remember $10 \%$ of what they read, $20 \%$ of what they hear, $30 \%$ of what they see, $50 \%$ of what they hear and see, $70 \%$ of what they say and $90 \%$ of what they say and they do.National Teachers Institute (2006) stated that Chinese concluded that: I hear I forget, I see I remember, I do I understand. Thus instructional materials cannot be left outside in the teaching and learning process especially in basic science, which is the bedrock of scientific and technological development.

\section{Influence of Gender on Achievement in Basic Science}

What has remained the main focus of great concern in the field of science education are the biases and misconception about women and science that is science is a male enterprise (Erinosho, 2005). Nwagbo (2006) stated that apart from factors like teaching method, and the teacher, gender is also implicated in students' achievement in science. The issue of gender in science classroom has always been a thing of concerned. Okeke (2007) observed that the consequence of gender stereotyping cut across social, economic, political and educational development, especially in the area of science and technology. However, there have been conflicting reports in respect to gender and achievement in science (Abonyi, 1998 and Ezeliora, 1999). Abonyi (1998) and Ezehora (1999) found that there is no significant difference in the achievement of male and female in science subjects. However, Okebukola (2002), Longe and Adedeji (2003), Yoloye (2004),Ezirim (2006) and a host of others noted that gender has impact on science education. Male supremacy and gender stereotyping are factors among others that were identified to influence occupational choice. Hence, Longe and Adedeji(2003) are of the opinion that science and technology is a male dominated subject and that females tend to shy away from scientific and technological fields. Boys therefore, appear to have a natural positive attitude to technical and science subjects while girls show negative attitude. This negative attitude appears to be due to the acceptance of the myth that boys are better in science subjects than girls. Babajide (2010) further admitted that science subjects such as physics and chemistry 
are given masculine outlook by education practitioners.

Ogunkola and Bilesanmi-Awoderu (2000)

carried out a research on the effectivenessof laboratory - based and lecture methods on students, achievement in Biology and employed a $2 \times 2 \times 2$ non randomized control group pretest - posttest quasi experimental factorial design, using Analysis of Covariance (ANCOVA) to analyze the data collected.They found that students' achievement in Biology was not sensitive to the sex of students.Bilesanmi Awoderu (2002) carried out a study on the concept mapping, students' locus of control, and gender as determinants of Nigerian high school students'achievement in Biology using Analysis of covariance to analyze the data collected, the researcher found that there was no significant main effect of gender on students' achievement in Biology.

Viann (2004) investigated differences and the effects of cooperative learning in mathematics classroom setting. The researcher used quasi-experimental design to compare a control section using individualized learning method with three treatment sections using cooperative learning strategy based on the learning together model of Johnson and Johnson (1991). The result revealed no significant gender - related difference but females obtained slightly higher grades than males. However, the present study wants to look at how the use or non use of instructional materials by teachers and how this affect students performance in basic science.

\section{Purpose of the study}

The purpose of the study is to investigate the effect of instructional material on the achievement of students in basic science.

The study will also find out if the influence of instructional material is based on students' gender.

\section{Research Questions}

1. To what extent does the use or non-use of instructional materials influence students' achievement in basic science?

2. How do instructional materials influence male and female achievement in basic science?

\section{Hypotheses}

1. There is no significant difference in the mean achievement scores of students taught with or without instructional materials.

2. There is no significant difference in the achievement of male and female students taught with or without instructional materials.

\section{Method}

This study,employed quasi experimental design. There was a pre-test posttest control group design. This design was useful to check the influence of instructional materials on the achievement of Junior Secondary School three (JSS 3) studentsin basic science. The population for the study was all Junior Secondary School 3 (three) students in Biase L.G.A of Cross River State, totalling about four thousand $(4,000)$ students. Four (4) secondary schoolswere randomly selected from the area of study. 60 JSS3 students were randomly selected from each school to form the sample for the study. Two hundred and forty (240) students formed the sample for the study

Two Schools formed the experimental group while the other two schools formed the control group. A 20 - item questions test called Diffusion Achievement Test (DAT) was constructed by the researcher. The test was trial tested on 20 students from schoolswithin the population but thatwere not part of the study sample.

Thereliability index was calculated using PearsonProduct Moment Correlation with a reliability index of 0.86 showing that the test was reliable. This test was administered to the control and experimental group as pretest.

Students in the two experimental groups were taught the concept of diffusion using potassiumpermanganate dissolve in water and spraying of perfume at one corner of the room as instructional materials. No instructional material was used in the control group. At the expiration of two weeks, DAT wasre-administered to the two groups.Scores generated were analyzed using mean, standard deviation and independent t-test.

\section{Result}

Hypothesis one: There is no significant difference in the mean achievement scores of students taught with or without instructional materials. 
Table 1:Mean scores of pretest and post testof students taught with and without instructional materials.

\begin{tabular}{|l|l|l|l|l|l|l|}
\hline \multirow{2}{*}{ Groups } & Pretest & \multicolumn{3}{l|}{ Protest } & $\begin{array}{l}\text { Mean achievement } \\
\text { Gain }\end{array}$ \\
\cline { 2 - 8 } & N & Mean & Std. Dev & Mean & Std. Dev & \\
With instructional & 120 & 57.4 & 11.86 & 74 & 13.64 & 16.6 \\
\hline $\begin{array}{l}\text { Material } \\
\text { Without instructional }\end{array}$ & & & & & & \\
\hline Mean difference & 120 & 36.1 & 19.33 & 47.5 & 17.08 & 11.4 \\
\hline
\end{tabular}

Table 1shows that the experimental pre-test and post testmean scores are 57.4 and 74.0 while their standard deviations are 11.86 and 13.64 respectively. The control group however has pretest and post-test means score of 36.1 and 47.5 and standard deviation of 19.33 and 17.08 respectively. Therefore, the mean achievement gain for the treatment is 16.6 while for the control group is 11.4 indicating a superiority of treatment group over the control group in the use of instructional material in the teaching and learning the concept of diffusion.

Hypothesis two: There is no significant difference in the achievement of male and female students taught with or without instructional materials.

Table 2: t-test of significant difference of the mean scores of male and female students taught with or without instructional material.

\begin{tabular}{|l|l|l|l|l|l|}
\hline Variables & \multicolumn{1}{|c|}{$\overline{\mathbf{X}}$} & SD & $\mathbf{t}_{\text {cal }}$ & $\mathbf{t}_{\text {cri }}$ & decision \\
\hline Males & 72.57 & 13.64 & 4.68 & 1.98 & Significant \\
\hline Females & 75.67 & 12.12 & 4.68 & & \\
\hline
\end{tabular}

Significant at 0.5 alpha level.

Table 2shows tcal to be 4.68 which is higher than the tcri of 1.98 . Thus the null hypothesis is rejected. There is a significant difference in the mean achievement scores of male and female students when taught with or without instructional materials, with female students being favored with a higher mean score of 75.67 as against 72.57 mean scores for male students.

Discussion

From the result of this study, the first hypothesis indicates that students taught with instructional materials have achieved higher than those taught without instructional materials. The result of this study agreeswith the earlier works by Inyang-Abia(2000),Sisteiland Harrison (2001) who emphasized that the use of instructional materials aid for effective learning. This study also agrees with the work of Brown (2000) who emphasized the roles of instructional material among which is ensuring retention and making learning more permanent.
The results of the study also show a significant in favour of female students on how instructional materials influence their achievement in basic science. The result of this study is in contrast with the earlier findings of Abonyi (1998), Ezeliera(1999) who found no significant difference in achievement of male and female students in science concepts. The study is also in contrast with the studies of Okebukola (2002), Longe and Adedeyi (2003), Yoleye (2004) and Ezirim (2006) who noted that gender has impact on science education, with male exhibiting supremacy in the science and technology field over females. However, the result of this study is in support of the findings of Viann (2004) who found no gender related

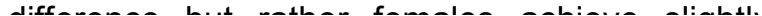
72 BEATRICE ARISA AROP, FELICIA IMEH UMANAH AND CONCLUSION 
Basic science is best taught with the use of equipment and instructional materials. Teachers should source for materials for effective teaching if standard equipmentsare not available. Teachers should use instructional materials at every point of the learning process for maximum learning outcome.

\section{RECOMMENDATIONS}

1. Teachers should source for instructional materials for effective lesson delivery.

2. Government should provide incentives to enable teachers acquire instructional materials where necessary.

3. Instructional materials should be simple and relevant to the topic.

4. Both male and female students should be given equal opportunity in science classrooms.

5. Government should provide instructional materials that are free from biases, stereotypes, distortions and prejudices.

\section{REFERENCES}

Abonyi, O. S., 1998. Effect of an ethno - science base instructional package on students' conception of Scientific phenomenon and interest in Science.Unpublished Doctorate Thesis, Department of Science Education, University of Nigeria Nsukka.

Adedayo, O. A., 1998. Differential effectiveness by Gender of Instructional method on achievement in mathematics at Tertary level.Educational Studies in Mathematics.Vol. 37 issue 1 PP $83-91$.

Babajide, V. F. T., 2010. Generative and PredictObserve-Explain Instructional Strategies as Determinants of Senior Secondary School Students Achievement and Practical skills in Physics. Unpublished Ph.D Thesis, University of Ibadan, Nigeria.

Bilesunmi-Awoderu, J. B., 2002.Concept Mapping Student's Locus of control, and gender as determinants of Nigeria high School students' Achievement in Biology. Ife Psychological Journal, 10, (2): 92 110.
Brown, R. M., 2000.Curriculum and Teaching an Introduction to Method of Teaching. Ibadan:Macmillan Press.

Bitiku, O. F., 2000.Improvisation in Mathematics in FCT Primary Schools: How far? $41^{\text {st }}$ Annual Conference Proceedings of STAN 339-341.

Crist, M., 2014. What are the importance of instructional materials in teaching Retrieved $10^{\text {th }}$ March 2014 from Employment blurtit com/2247194/

Erinosho, F. E., 2005.Women and Science.38 ${ }^{\text {th }}$ Inaugural Lecture, Olebise Onabanjo University: Ago - Iwoye, 1 - 37.

Ezeliora, B., 1999. Effects of learning material on students Achievement and retention in chemistry unpublished Ph.D Thesis. Department of Education, University of Nigeria, Nsukka.

Ezirim, M. U., 2006. Scaling up girls Participation in Science Education: Towards a score card on quality Education. E. Okeke and M. Opera (Eds) Science Teachers Association of Nigeria. Gender and STM Education series (1).

Eya, P. E., 2004. Instructional material procedures in a challenge Education system. Paper presented at the Annual natural conference organized by curriculum Development and Instructional material Centre (CUDIMAS). University of Nigeria, Nsukka.

Fakunle, I., 2008. Enhancing the teaching and learning of mathematics through Effective utilization of instructional meterials. Journal of Teacher Education, 9, (1): $102-111$.

Inyang - Abia, M. E., 1994.Essentials of Educational Technology. A Hard book of Education and media Partitions. Uyo: Legacy Nigeria Ltd.

ljaduala, J., 1997.The Effect of Instructional Materials on the Learning and Teaching of Economics.Naira Project.Com/Project/250.Htm 
Longe, R. S and Adedeji, S. O., 2003. Increasing girls access to technical and vocational education in Nigeria. O. Ayodele Bamisaiye, I. A Nwazuoke and A. Okediran (Eds). Education, His millernium - innovations in Theory and practice Ibadan: Macmillan Publishers Nigeria.

Maduabum, M. A., 2000.Teaching Integrated Science Effectively. Onitsha: Space MartrickPublication Ltd.

National Teachers institute., 2006.Improvisation of Instructional Materials, NTI Manual, Kaduna.

Nursel, F. A., 2001. Instructional Design, Springheld: Charles O. Thomas Publications.

Nwagbo, C. R., 2006.Effects of two teaching methods on the Achievement and attitude to Biology of students of Different levels of Scientifics literacy.international Journal of Educational Research.45, 216 $-229$.

Ogunleye, B. O., 2002.Evaluation of the Environmental Aspect of the senior Secondary School Chemistry curriculum Ibadan Nigeria.Unpublished Ph. D Thesis University of Ibadan. Nigeria.

Ogunkola J. B and Bilesanmi - Awoderu., 2000. Effects of Laboratory and lecture methods on students' Achievement in Biology.African Journal of Education, 5, (2): 247-260.

Okeke E. A. C., 2007.Making Science Education Accessible to all. $23^{\text {rd }}$ inaugural Lecture series University of Nigeria,Nsukka
Okebukola, P. A. O., 2002.Beyond the stereotype toNew Trajectorusin science teaching.Published by STAN.Printed by. Taste and styles RH 13:Cultural Complex Abuja

Sisteil, C and Harrison, D., 2001.Fundamental of teaching with Instructional Aids. New York: Macmillan Publication

Yoleye, T. W., 2004.Increasing female participation in Science. Mineograph. University of Ibadan Nigeria.

Usman, K. O and Adewumi, A. O., 2006.Factor Responsible for inability of teachers to improvise instructional materials for the teaching of mathematics. JSTAN 41, (1\&2): 51-56.

Usman, K. O., 2002. The need to retrain inservice mathematics teachers for the attainment of objectives of Universal Basic Education (UBE) the journal of the mathematical Association of Nigeria ABACUS 27, (1): 37-44.

Viann, E.,2004. Gender Differences and the effects of cooperative learning in collect level mathematics. University Ph. D Thesis Curtin University of Technology. 